\title{
Rhizomes: Cultural Studies in Emerging Knowledge
}

Issue 3I (20I7) » https://doi.org/I0.204I5/rhiz/o3I.eo5

\section{Lay Psychoanalyzing Palestine as a Zionist Nightmare}

\author{
Rebecca Katherine Hirsch
}

(thanks to Megan Bailey)

Like an individual in thrall to his passion, his perversity, and his symptom, a nation can be both self-defeating and unerring in its aim. But if it is relatively easy to acknowledge this of individuals, it is far more shocking to consider that a nation, apparently inspired, believing fervently in its own goodness in the world, might be devoted not only to the destruction of others but to sabotaging itself.

- Jacqueline Rose psychoanalyzes Israel in The Question of Zion (2005)

[1] Hypothetically, let's say that "Zionist" is equivalent to "oppressor." That Zionism's achieved dream of Jewish freedom comes at the direct expense of anyone who isn't Jewish (and the indirect expense of those of us who are). Let's say that a Zionist in practice resembles to some extent an overlord whose fetishization and pathologization of Palestine speaks less to any reality of place so much as it works as a symbol of obstruction and complication to a Mythical Dream. Let's say, in the Zionist imagination, Palestine is shorthand for destruction; a big, blocky embarrassment like your underwear showing when you're trying to give a toast to the President at a Gala on the Riviera. Let's say Palestine is a deeply cathected $^{[1]}$ and shameful obstacle to the celestial dream of freedom-to-be-a-specific-kind-of-people on which Zionism is based. 


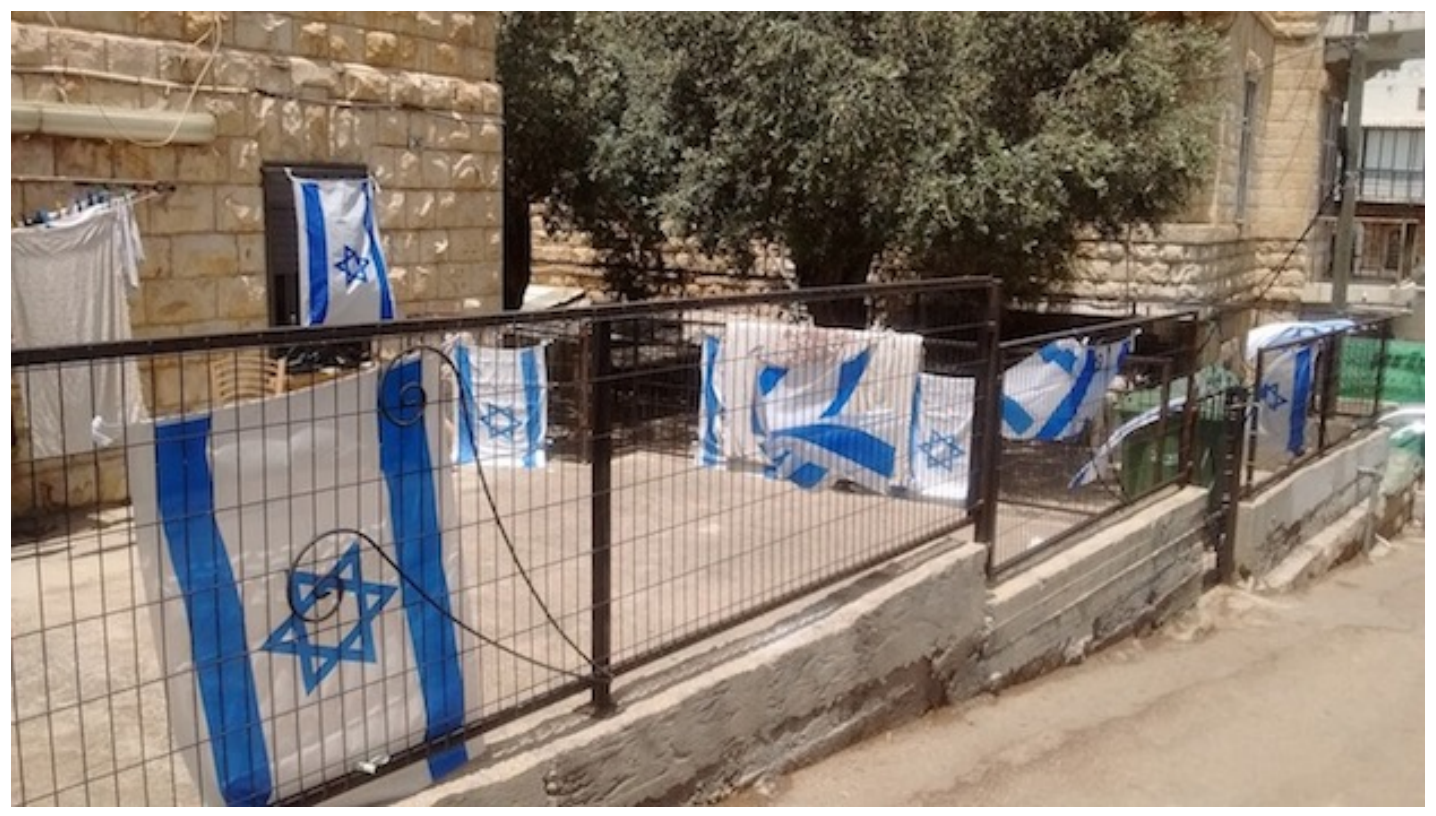

[2] But I'm not really talking about Zionism in isolation. I'm talking about Ideology, propaganda — hasbara — the fantasies and dreams and rehabilitating sense of not being abandoned and denigrated but wanted, valuable, loved. Zionism founder Theodore Herzl's "If you will it, it is no dream" seems unintentionally pertinent here, as everywhere. What we believe, what we want from power, what we actually do when we get power and who we see as our co-conspirators or enemies are all influenced by dreams, fantasies and nightmares, amongst and because of history, familial instruction, social rewards and punishments. Zionism is the kind of dream that makes perfect sense in contexts of deprivation or compelling storylines. It's the kind of dream that moved many Americans to vote for Donald Trump. A dream like Zionism relates to a number of overdetermined systems of oppression from racism and settler-colonialism to messianic, nationalistic True-Believerism. Zionism inspires people; inspires love and allegiance, affirmation, gullibility, nostalgia and fear, like any ideology.

[3] But I'm not really talking about Zionism definitionally — Zionism as the movement to establish a Jewish home in Palestine. I mean Zionism as a corollary, the post-1948 epilogue of Zionism as a realized goal that transmogrified into an ideology, a life force. [2] I mean Zionism as a soured and superannuated childhood want. Nor am I talking about any imagined monolith called The Jewish People (a diverse group

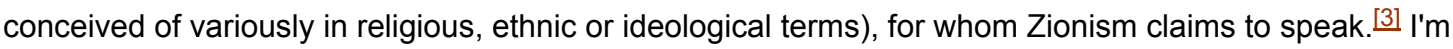
not even talking about Zionism as an ideal, but the post-victory fractured thing it created, and how this has applications beyond Zionism to desires and dreams felt by any bedeviled group trying to get out from under the heels of others by stepping on someone else, the bullied becoming bullies, the abused becoming abusers - whether accidentally or intentionally (to their victims, it doesn't really matter). Zionism is the ideology that undergirds and motivates Israel (and it predates the state by 60 years) but the underlying philosophy is not unique to Zionism or Israel or the Jews. It can be found in similar 
projects like apartheid in 20th c. South Africa, police violence in America, the colonization of America in the past, the Hapsburg Empire, the Ottoman Empire, the American Empire, the Japanese Empire, any empire. A psychology of Zionism can help us better understand how systems of oppression are created and sustained in the past and present.

Zionism and Palestine, or: dreams that depend on the destruction of others

[4] Zionism succeeded by all of its own terms, but the romantic ideological want that succeeded doesn't match its utopian millennialism. Its manifestation is something strange and broken: Zionism as accomplished desire in which Palestinians are unacknowledgeable, unseeable, who can't exist for the believers of the fantasy because the fantasy doesn't include them, because it doesn't believe that they exist - or if they do exist, their existence threatens the nobility of Zionism. Zionism won. But what did that win create?

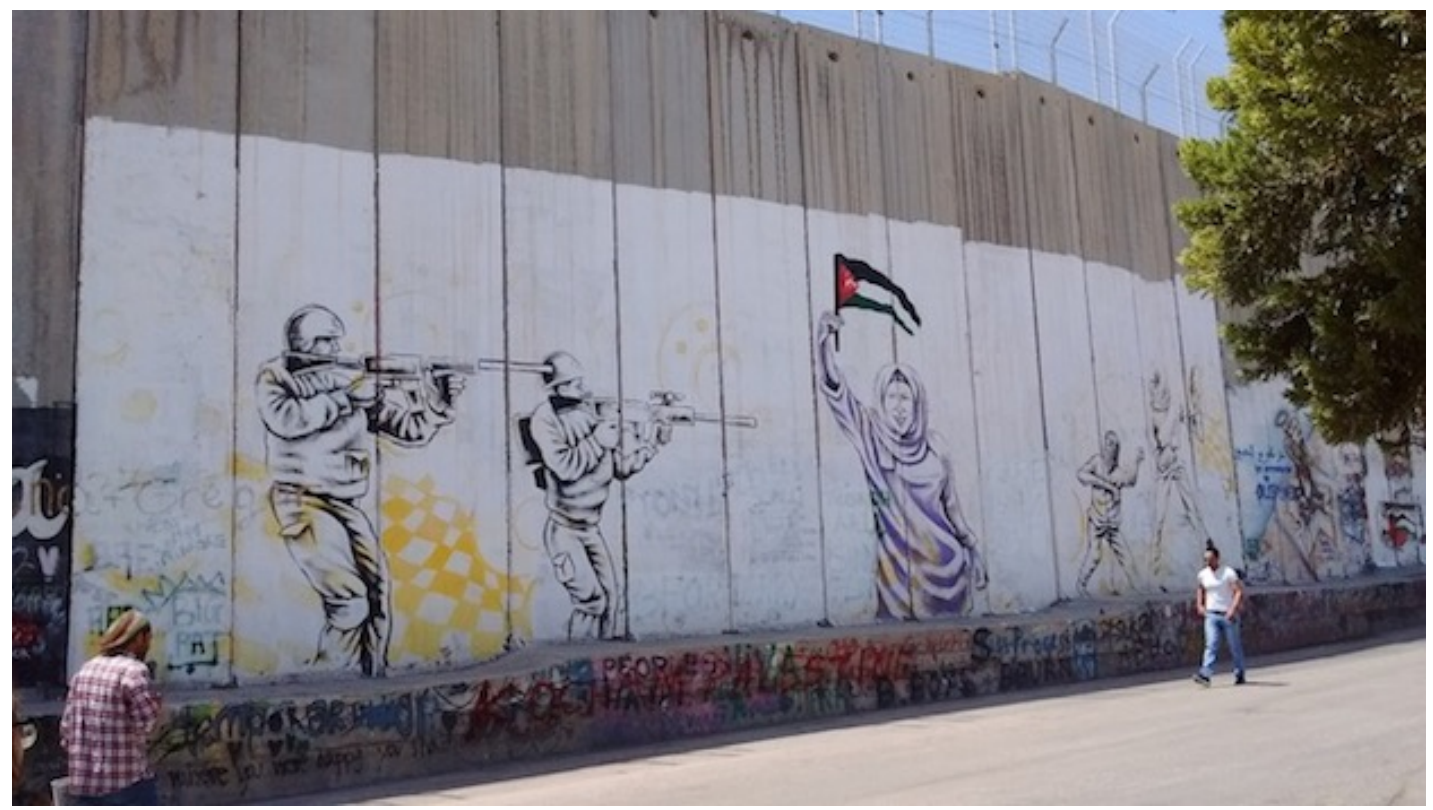

[5] Zionism looks like freedom but manifests as domination; a kind of sexualized projective hatred of Others who resemble oneself. A "Jewish homeland" in 19th century terms could have been in Uganda or Madagascar but Herzl and his proponents chose the more utilitarian, pragmatic (e.g. more Jews would embrace it because of its symbolism and history) location of Palestine. In order for Zionism to create an Israel, there had to be a de-creation of Palestine. It wasn't personal; Palestine was just in the way and had to die if Israel were to live (not that all Zionists, and certainly not all Jews, desired that outcome). In that frame, I think we can call Palestine a Zionist nightmare, ${ }^{[4]}$ a real-life impediment to the dream.

[6] But one more thing: I'm not really talking about Zionists. I'm talking about anti-Zionists, and postZionists and anteaters. A Zionist nightmare isn't something to which only ostensible Zionists have 
access. Seeing Palestinians, or women or members of any marginalized group, as symbols and ghosts instead of people is something we all potentially do (indeed, anyone's potential for, or access to, any ideology is variously determined by a whole slew of overlapping and complicating socio-economic, regional, historical, mytho-chaotic, time-and-space-based factors). We could have been/may yet be otherwise. This essay isn't really about Palestine, or Zionism, at all. It's about Ideas of Ourselves and the Uses of Others to Assure Ourselves that we are Ourselves, or at least people we think we are or want to be; good, moral, the kind of people we like, or can at least tolerate. How do we deputize whomever (or whatever) - people, nations, ideas - to fulfill our self-conceptions? ${ }^{[5]}$ My argument in this article is that a "Zionist mindset" is something we all have access to, whether we visit Zionism or live in Zionism all the time. I'm talking about Zionism in the same sense as patriarchy, or white supremacy, the fantasy that we (the dominant group, by birth or aspirational identification) are Good and others are Bad, or at least worse, and definitely not as civilized or deserving. I indulge in the same fantasies as Zionists and maybe you do too. We all contain potential for cruelty and condescension (rather: we are all capable of holding oppressive ideologies, though the extent to which we can act on those ideologies and oppress, or otherwise have a negative impact on other people is variously determined by class, race, sex, region, citizenship, age, etc.); however, recognizing this potential (not necessitating acting on said potential) is a good starting point to taking responsibility for ourselves. So often, what we call "Other" is just a funhouse mirror version of ourselves. As James Baldwin put it, "I'm not talking about you when I talk about you, I'm talking about me."[6]

Psychoanalysis: A Helpful Frame

[7] A psychoanalytic framework to apprehend Palestine may seem like a shortsighted one, but I demur! In confluence (not isolation) with socio-economic world-stage-historical frames, psychoanalysis can offer many useful ways of looking not just externally but internally at chronological underpinnings for behaviors and desires and learned identities of political and emotional states, as is done with individual patients. Psychoanalytic frames can contribute a wider breadth, a palimpsest history of overdetermined motivations, contradictions and defense mechanisms that peoples use (unconsciously) to protect themselves, contend with themselves and tell themselves they are themselves.

[8] At best, psychoanalysis can help humble and empower, reminding us that our worst enemies are not always those outside ourselves, but camouflaged within us, and hence available to be understood. "Enemies," in fact, could be misunderstood desires (e.g. women called sexy or evil if sexuality — or intimacy or vitality or whatever one associates with sexuality — is considered scary or sinful; women can thus be scapegoats for patriarchal fears and desires, just as queer people may be called deviant or "unnatural" for the same reasons) and so by understanding our desires and defusing our fears, we may have less reason to scapegoat others, projecting our fears onto others when we're not comfortable holding them ourselves. Psychoanalytically, desire is not condemned as an "evil" or sinful essence but rather accepted as human material to be examined; not tamed or extinguished, repressed or ignored. The issue is never the vilification of any feeling but rather: awareness of the difference between desire and action, between wishes and their realization, or subversion. Essentially, the more we respect our 
desires - whether for conquest or overthrow or invalidating whole swathes of people - the more we can feel those desires as valid and informative without confusing them for reality by recklessly acting on them or impulsively blaming them on those with less political power to fight being wrongfully blamed.

[9] I think it's useful to frame Zionism in terms of desire and examine it psychoanalytically because if understood and respected, desires can be managed, rather than metastasized and sped out of control. So many desires for conquest, victory, normality, love, destruction, impunity, the desire to be the best, and the desire to have a recognizable, familiar storyline (e.g. "the lachrymose history of the Jews/world's eternal victims") coalesced in the formation of Israel. There's nothing wrong with these desires; the problem is acknowledgement of reality. Desires for death, life, etc are basic, human and not worthy of shame. But because these desires aren't acknowledged and accepted, these desires can never rest or get sublimated into more productive tasks... like achieving peace and justice. These desires remain uncomfortable and thus are bluntly projected on scapegoats. Thus, while all parties may engage in violence, only Palestinians are blamed wholesale as terrorists, while Israelis frenetically cling to the rickety narrative that their violence is only the violence of good, defensive underdogs.

[10] This analysis has been especially influenced by Jacqueline Rose, who uses feminist and psychoanalytic frameworks to produce critical scholarship focusing on literature and politics. I am particularly indebted to her book The Question of Zion (itself indebted to Edward Said's The Question of Palestine), which is a graceful, relentless excavation of feelings and fantasies enabling politics. ${ }^{[7]}$ Rose uses analytic principles (and incredible clarity and elegance) to plumb Zionist politics; investigating how the inner worlds of Zionism's ideators influenced its manifestation, and why Zionism psychologicallyideologically pulls so many people today, from the historical and generationally passed-down influences of trauma, shame and embarrassment to the power of messianism, mysticism and destiny in forging group identities calcified in the form of a nation. Rose discusses how nations normalize/neutralize/take the sting out of anything that would be considered much worse if done by an individual or powerless group of rebels (e.g. state violence against native people, land rights, favoring one group of people over others to the extent that laws, citizenship, everyday resources and eventual mortality are all created and manipulated to privilege the favored group). I am particularly influenced by the way that Rose uncovers and untangles past and present in the aim of understanding retributive patterns of violence and the psychological purposes of scapegoats.

[11] Psychoanalysis can also help us understand contradiction, the "cognitive dissonance of... Zionists who consider themselves in favour of peace, human rights, and justice, yet have to square this with support for a militarised ethnocracy founded on mass expulsion of indigenous people" (Landy 2011:137). When I first visited Palestine — the Stars of David graffitied on Palestinian houses, $\frac{[8]}{\text { the settlers }}$ swaggering with guns and soldiers harassing Palestinians at checkpoints - I wondered: why is it that oppressors can't see their own oppressiveness? How is it possible that villains think themselves victims, or heroes? ${ }^{[9]}$ These foundational folkloric categories — villains, victims, oppressors, oppressed — are situational placeholders, identity purgatories. They're not real in the sense that they aren't exhaustive. No one is anything all the time. We don't live inside any category forever. We are created and re-created in 
our changing contexts: via our actions and beliefs, the passing of time and expedience of situations. We are not bound by essences eternal or infrastructural. No one is a constant hero. One person's hero is another person's hindrance. For example: Jews are not inherently funny; dancers are not inherently coordinated. Jews can become dancers. Coordination: funny? In other words: Identity is fluid and layered. As Edward Said (1979:143-4) puts it, "when we speak today of the Arabs, or the Lebanese, or the Jews, or the Israelis, we seem to be speaking about stable entities whereas in reality we are talking about interpretations that are highly volatile and even more highly speculative." Identities are not stable, and always up for interpretation. Situations enable different aspects of our personalities and training creates new skills. Basically, we all contain potential to be and behave in different and unexpected ways, becoming versions of ourselves we might not have known we possessed. Zionist fantasies and philosophies of Palestine create realities of oppression that oppress Palestinians directly and corrode the ethicality of Zionists for so oppressing.

[12] Here's a belief I have: Material realities create social ideologies which create psychologically internalized beliefs. To put it another way: emotional and physical conditions lend themselves to the creation of collective narratives, the function of which is to explain situations or provide meaning or succor. These collective ideas are then integrated personally by individuals in individual ways, yet they nonetheless derive from the same socio-cultural source because we all swim in the same sea (even if we're different fish, so to speak). Nothing has always been any one single kind of way. Who we are is based on what is around us. Taking this to Palestine/Israel, when a member of Israeli police or the Israeli army kills a Palestinian teenager, what taken-for-granted ideologies and atmosphere of the surrounding climate create that ease of murder? For example, the adrenaline-fueled ethos of bystanders shouting "Death to Arabs!" 10$]$ and "Shoot, shoot!" 111$]$ This cultural attitude obviates the need for trials, makes immediate and socially acceptable an adulation of (some peoples') death (in practice, if not in theory). 


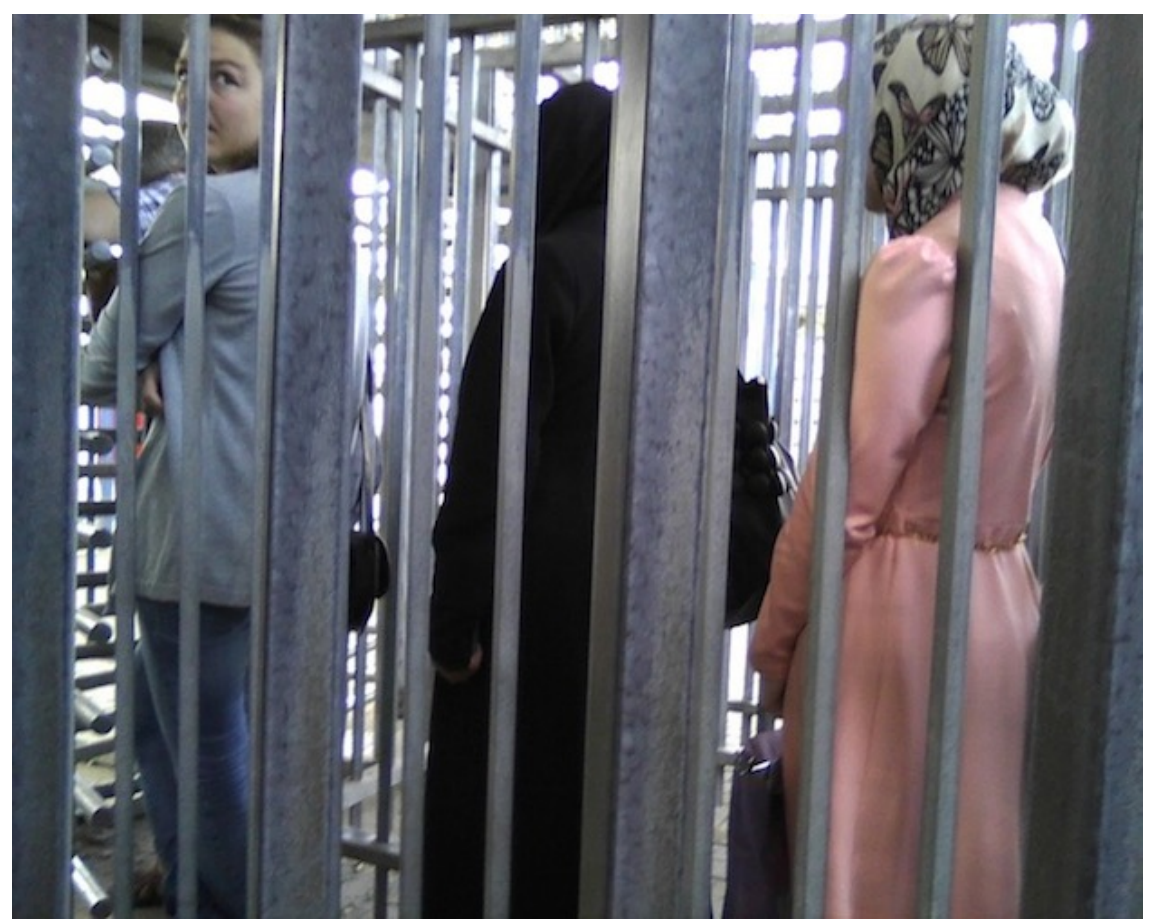

[13] But oppressors are just people, people like us. Oppressors and oppressed are transferable concepts that encompass different groups in different periods. I'm talking about mentalities and attitudes and power, which alight on groups and nations but aren't bound by them. Zionism is - among other things an attitude that needs scapegoats and enemies. Palestine is the obstacle to the unrealizable dream of Jews as safe, Chosen, and representative of all people (a dream that could perhaps better be realized in heterogeneity and humility).

[14] People who oppress - and "these people" are not a constant; many oppressors have formerly been oppressed - are immersed in politically expedient, socially-understandable-within-their-subgroup narratives and national or ethnic-religious storylines. Fantasy is powerful. It can obfuscate reality. For example: I love cats. Do you have an excellent dog? I might not be able to see it as I have already decided that cats are the best.

[15] Our personal and cultural ideas are informed by legends of the past which become calcified in their retelling: the lachrymose history of the Jews, the inherent violence of the Arabs, the Arabs and the Jews are indelibly different groups of people, they will never live together in harmony, etc. These oft-repeated beliefs stagnate into myths that belie the actual history of Jews and Arabs living together perfectly well without murdering each other. This was the case in the 700s-1100s Spanish Golden Age (Cohen 1994, Menocal 2002). Jews were generally safe and integrated into society in the majority of the Arab world pre-1948 ${ }^{[12]}$ and Jews and Arabs were regarded as being literally the same people, as we can see with $50 \%$ of the Israeli Jewish population being Arab/Eastern/Mizrahi (Lavie 2011). 
[16] Zionism is a dream of freedom that comes at the direct expense of the morality of oppressors and often the lives of the oppressed. While it's the oppressed parties who actually get killed by oppressors, the oppressors are spiritually killed by themselves, by tunnel-vision focusing on victory for one's own self and group. Many early Zionist ideas posited the Jews as monolithically representative of all people, hence the salvation of the Jews benefited everyone (e.g. "Israel's problem was but a distinct form of the universal human problem. Accordingly, the task of Israel as a distinct nation was inexorably linked to the task of humanity in general" (Silberstein 1989:100). This corresponds sloppily with another Zionist belief that Jews are exclusively Chosen. Not only do these two ideas cancel each other out, but Zionism easily loses on both fronts: Salvation and freedom of Jews cannot come via obsessions with safety/defense/security and social ideologies of Chosen-ness and a kind of Jew-centrism that discriminates against non-Jews. The Zionist mindset is a cocooned, paranoid, militantly rule-following one. This hasn't made anyone safer, not Jews-as-collectively-representing-the-world, not Jews-asuniquely-out-of-this-world; quite obviously not Palestinians who've been under the heel of the Zionist dream for decades. Zionism: Bad for Palestinians, but is it good for the Jews? No. Hatred-fear of anyone always doubles back, the consequence of Zionism's not having the bravery to "face its own dark beast," to "make room for the foreigner in its midst (or even more radically perhaps, see itself as the stranger for the Arabs in Palestine)" (Rose 2005:86). Palestinians, as Edward Said put it, are "the victims of the victims" and while Jews may not be "directly" negatively affected by Zionism, our case is easily paralleled with that of men who aren't "directly" negatively affected by patriarchy but who are instead encouraged to kill all potential for empathy and comradeship across gender lines and painfully stuff all their discomfort down into repression that boils over into blame of any defined-as-opposite Others such as women or queers or anyone associated with femininity, etc.

[17] I think that when anyone is trained to hate, they hate. Especially when that hatred comes under cover of love, and obligation. In Israel, military is mandatory, adulated and enmeshed in culture. Thus, militarism becomes normal, and glorious. A proud and bombastic mainstream Israeli Zionist hatred of Palestinians emerges out of the normalcy of militarism and the self-protective and self-congratulatory claustrophobia of Jewishness. In close-knit martialism, dissent is not brooked. Human rights are belittled or lambasted. A society of hatefulness is created by design. In such a society, people can kill without charge,$\frac{13]}{13}$ be arrested on account of Facebook statuses $\frac{[14]}{}$ and when prompted, unleash the violence for which they've been trained — via schoolbooks $\frac{[15]}{15}$ and national mythologies. $[16]$

Palestine is a real-life nightmare in the Zionist dreamscape. What kind of nightmare? Let's take a look.

Palestine as Nightmare of Envious Unconscious Identification

[18] Palestine re-activates an angry identity crisis by confounding David-and-Goliath narratives of Jews as scrappy, resilient Davids. Zionism requires Jews to be victorious victims beset perennially by attackers. As Israeli education minister Naftali Bennett put it, "For the past 120 years, people are trying to kill the Jews here. The enemy changes, but we remain here, growing and building our land. We are the eternal nation, and we are raising our heads. Jewish heroism will defeat the enemy" (Khalek 2015). The created 
need for an enemy based on past fears results in present scapegoating of Palestinians. For, "the mind is... a palimpsest, its inheritance imperishable. Latent within us, we carry the traces of those parts of the personality that our predecessors inhibited and that never completely disappear" (Rose 2005:94). Like many American Jews, I was taught that intelligence and resourcefulness were inherent to the Jews, not dissimilarly to how sexiness, for example, is attributed to women. But circumstances create attributes that are then deemed non-contextually inherent. The mournful brainpower that I was taught was "Jewish" exists perfectly well in Palestinians. This leads one to believe a few things: For one, scrappy, intelligent resourcefulness as an identity was never an inherently Jewish thing, no matter what Philip Roth/Woody Allen-style American Ashkenazi legends would have us believe. Like all other archetypes, it isn't inherent or eternal in anyone. These are qualities that are likely to emerge in situations of oppression requiring know-how to survive. I am reminded of the phrase "women's intuition" to denote an apparently coy, thoughtful, indirect intelligence deemed inherent to women as a monolithic class - this concept could realistically be attributed to any oppressed group that doesn't have the social power to assert itself directly ("Most women learn that for their own safety... they had better try to understand and predict the behavior of men, But this is not a female skill; it is a self-protective skill... In a brilliant experiment on women's intuition" it was found that "the person in the subordinate (follower) position was more sensitive to the leader's nonverbal signals" (Tavris 1992:332).

[19] It would thus be more accurate to call "women's intuition" subordinate's intuition and "Jewish intelligence" subordinate's intelligence. Given the exigencies, groups of people have the abilities to be many things. The compensative supplanting of the Nebbishy Jew stereotype by the Muscular Zionist New Jew stereotype ${ }^{[17]}$ was meant to obviate anti-Semitic European associations of Jews with weakness. However, within a new Big and Strong stereotype, there is still comfort in the old Weak Nebbish stereotype. Thus, the overdog culture of Israel still identifies as underdogs resulting in a

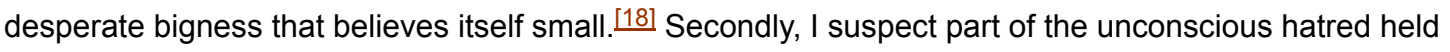
perhaps by Zionists for Palestine is misdirected envy and confusion about roles and identities and legends of who we, the Jews, think we are. Intelligent, brave Palestinians complicate many Jews' ideas of ourselves as golden underdogs, which leads us to...

Palestine as Nightmare of Unacknowledged Privilege

[20] Very powerful people often legitimize their abuse by claiming that they are abused and powerless. They may have been! But Palestine complicates Zionist narratives of Jews being in constant pain, always ultimate victims. I conceive of Zionist privilege as the expectation that one is a prodigal son coming home to one's loving, long-awaited homeland. It is painful to confront dashed dreams, admitting we're not special, coming down from pedestals, of having to be responsible adults instead of aw-shucks Dennis the Menaces. We want to be home, we want to be loved. We may have been abused. We may have been in pain. Now we just want to be free. But what to do when that freedom crashes into the dreams of others who ALSO want to be free? ${ }^{[19]}$ Zionism is all about Jewish (Ashkenazi) safety and desire, it has nothing to do with Palestine (or Palestinian Jews, or marginalized groups such as Ethiopian or Mizrahi Jews in general). Palestine forces the fantasy to face itself, uncomfortably. 


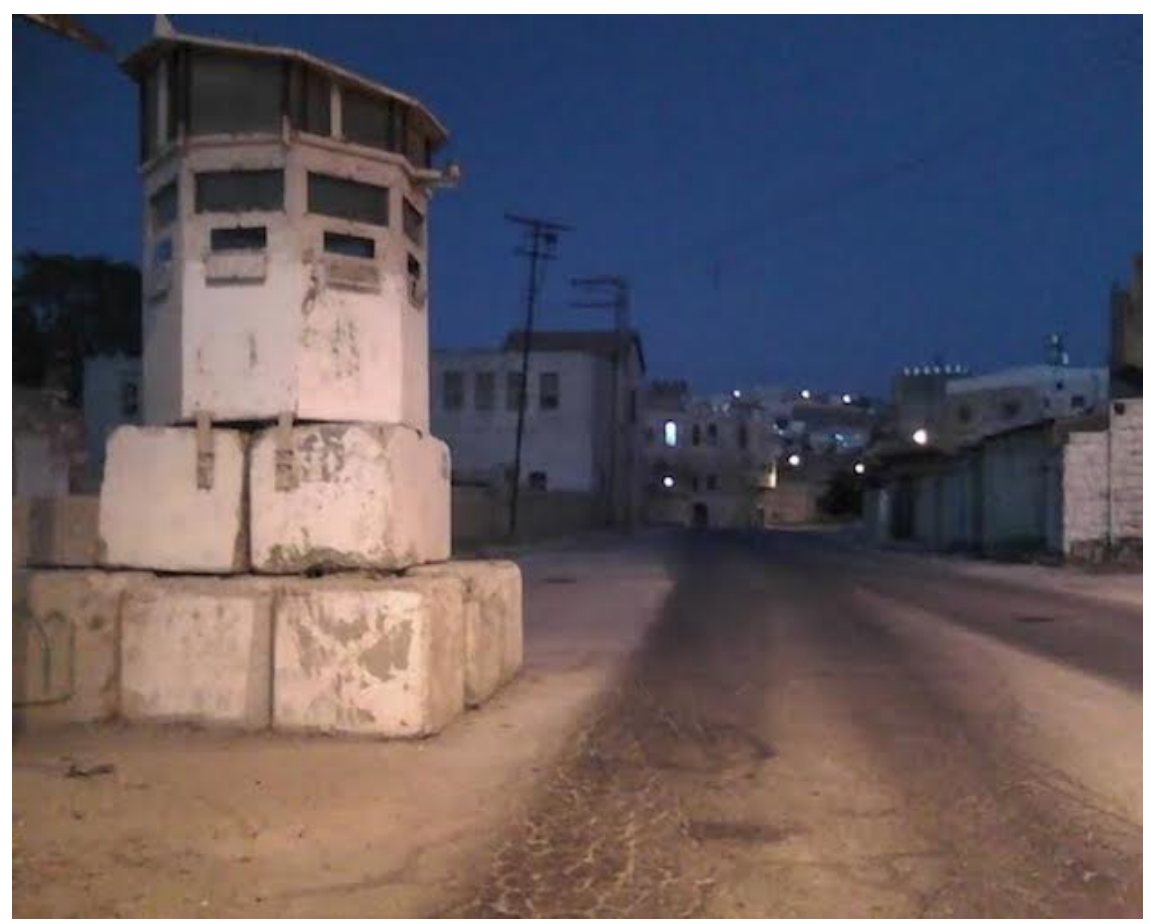

[21] For a group to admit it might not be Chosen (or entitled to privilege) but is instead just like any other group is a difficult, uncomfortable revelation of identity, and growing up. It's difficult even to think of all human groups as horizontally similar rather than vertically dissimilar. If you believe that your nationality/group/team/religion is the best; well, so does everyone else. We all think we're protagonists. When a group of people with oppressive attitudes gets way too much power, impunity, and anonymity, without oversight, external compulsions to behave, or socially acceptable opportunities to unleash anger, misdirected frustration, and angst, this results in oppression of others.

[22] Although political "security" might motivate Israel's actions more on the surface, holdover mythologies of "chosenness" are still influential — just not as inherent to Jews, or any group. After all, what may be called "chosenness" is similar to any other nationalist ideologies' unifying myths. Again: We all think we're protagonists. This is a helpful tool for either resisting power or maintaining it. Anti-Semitic perversions of anti-Zionism certainly exist but I don't want to attribute Zionism to anything integrally Jewish so much as understand how past powerlessness can create present powerfulness, and how fears of the past can get locked in the present. Oppressor mentalities are not inherent to any group and can thus be forgone. This represents a hope for change.

Palestine as Nightmare of Humbert Humbert Sleaze and Masculinist Sex-Negativity

[23] Here's an idea: An obsession with or complacent acceptance of violence bespeaks concealment of something else. I posit that violence is not a direct desire, not a "natural" end (what is "natural" outside of human ideas of nature that vary by era and place, position and politics?) but a coping mechanism that 
hides something deeper and more essential: sensuality, intimacy, connection. These things, of course, look different to different people but the basic desire to feel good is foundational - reflecting back to the needed comfort - or at least food and shelter — provided by one's earliest caretaker. When that need is confounded, it is channeled elsewhere. In other words, unable to be expressed directly, it finds expression indirectly. $\stackrel{[20]}{ }$ In patriarchal, militant societies based on exclusion and the appearance of toughness to hide from human vulnerability and hunger for connection, violence is the only route available for needs that cannot be eradicated. To put it another way, where you aren't allowed to hug or cry or have a conversation, but are given a gun and orders to use it, violence might emerge where intimacy is stanched. The need doesn't go away, but its direction is re-channeled (displaced) into the nearest available receptacle: violence.

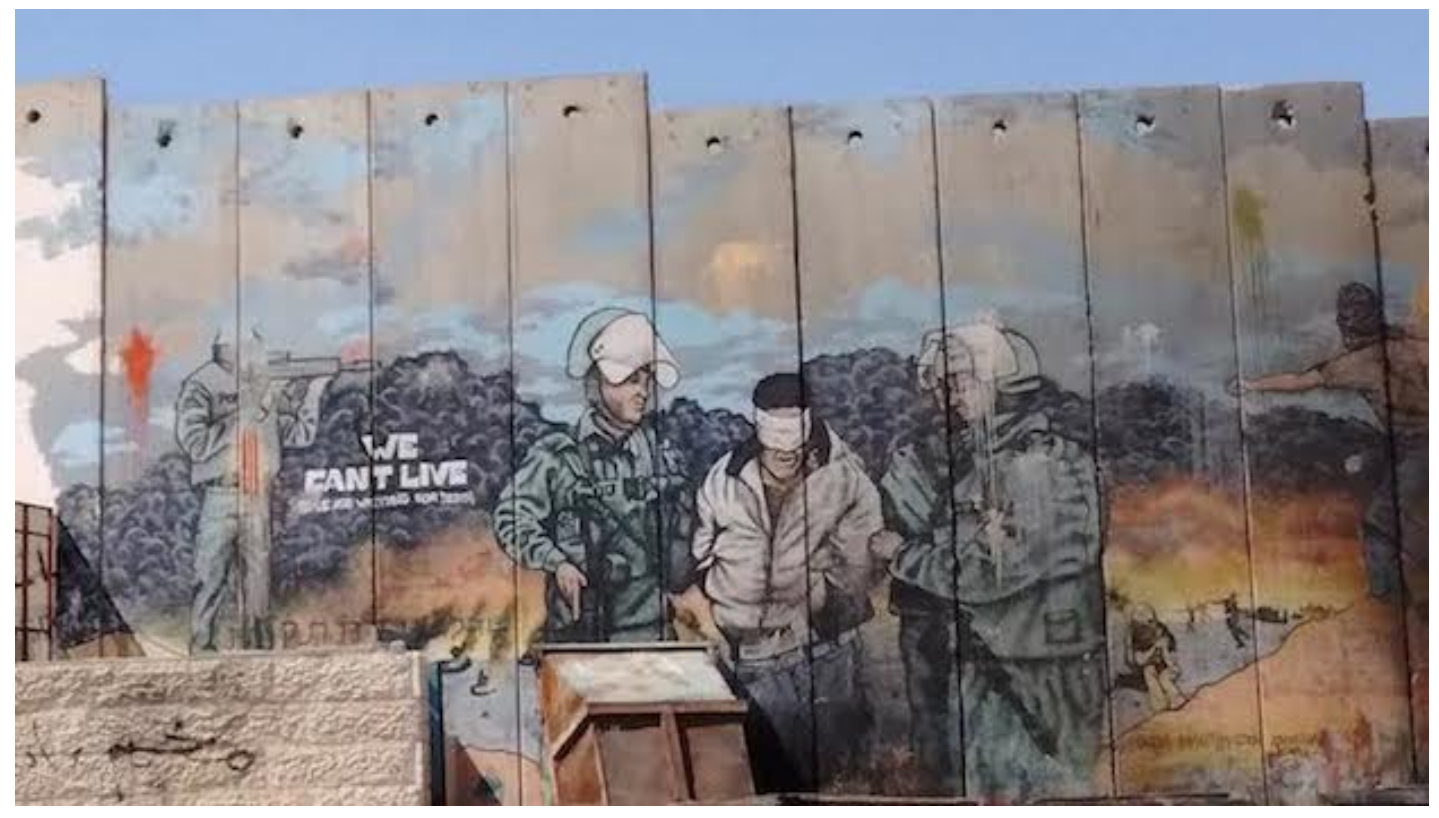

[24] Where essential sensuality is culturally verboten, this basic unmet desire is unable to achieve a direct, healthy channel through reciprocal connection. It is thus perversely redirected onto the outlet society provides. In a martial, hierarchical society this will often take the historically patriarchal form of violence.

Palestine as “Freedom” Impediment

[25] Zionist arguments about freedom are rather Orwellian, very "I want the freedom to deny you your freedom!" ("Everything is for the Jews! Not a single piece for other people! That's what I believe!"[21]; "You are invited to be a world citizen. It's your choice, my friend."[22] This makes sense, because freedom in a Zionist frame was never about non-Jews. Zionism is about (Jewish) FREEDOM writ large with all the loudness to shunt aside (healthy) fears and doubts and awareness of complex desires about what exclusivist freedom might actually look like. "Zionism, as a unique national movement, had the 
opportunity to forge a model of nationhood, neither belligerently nor preemptively, but ambivalent, uncertain, obscure... disquieting and transformative space. But did not take it" (Rose 2005:86). Sociopsychologically, it may require a degree of confidence and (internally felt) security too great for Zionism to be comfortable with uncertainty. Zionism was born out of insecurity and compensative selfaggrandizement, in a 19th century European colonialist model that dispossessed Palestinians [23]: freedom via land and nationhood, in which indigenous or non-European peoples are pesky impediments to the Dream. $\stackrel{[24]}{ }$ What emerges as freedom in this schema is not comfortable allowance for human discomfort and a secure-in-oneself (or one's nation) willingness to just get along but rather insecure domination over Others who are scapegoated with representing our worst, feared selves. This FREEDOM then goes on to justify its manifestation on the original ideology's promise: Freedom, from oppression, for the Jews. Thus, Jews in Israel have the "right" to "defend themselves." But from attack, or from criticisms of the Dream? Hearing Zionists talk about freedom is very shiver-inducing: mechanical and puppet-like, like advertisements; lobotomized miming of the words of Authority and Official Dictums without reflection, without flinching; talking about death like it's nothing.

Palestine as Nightmare of Unresolved Trauma

[26] Oppressor mentalities are coping mechanisms run amok. The usefulness of these coping mechanisms is contextual. What helped you in one situation hinders you in another, e.g. if you dissociated as a child to survive living in a home with abusive parents, that survivalist distance might not be helpful in an adult relationship requiring more connectiveness. $\frac{[25]}{2}$ Mythologies of importance can help sustain oppressed groups, such as Jews in an anti-Semitic world, but once the formerly oppressed group is in power, these narratives outlive their uplifting purpose. $\underline{[26]}$

[27] Circumstances change faster than identities. Stories hang on, festered into fear-based entitlements, puffed-up bravado, living out the fantasy of being a superhero cop character who just arrived and

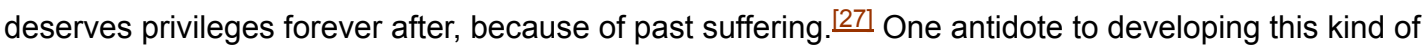
absurd oppressor attitude is essentially unlearning privilege on a psychological level that becomes actual in practice and then melds into the political. By which I mean putting away practically the power you've already put away psychologically. Not that it always goes in this order. One can't will empathy into being, just as one can't compel jokes or bravely accept vulnerability instead of running away and shooting at it. Sometimes, as in the case of Israel, that has to come from outside because there's no will to start the process oneself, inside. Not enough internal bravery, because there's not enough external social support. 


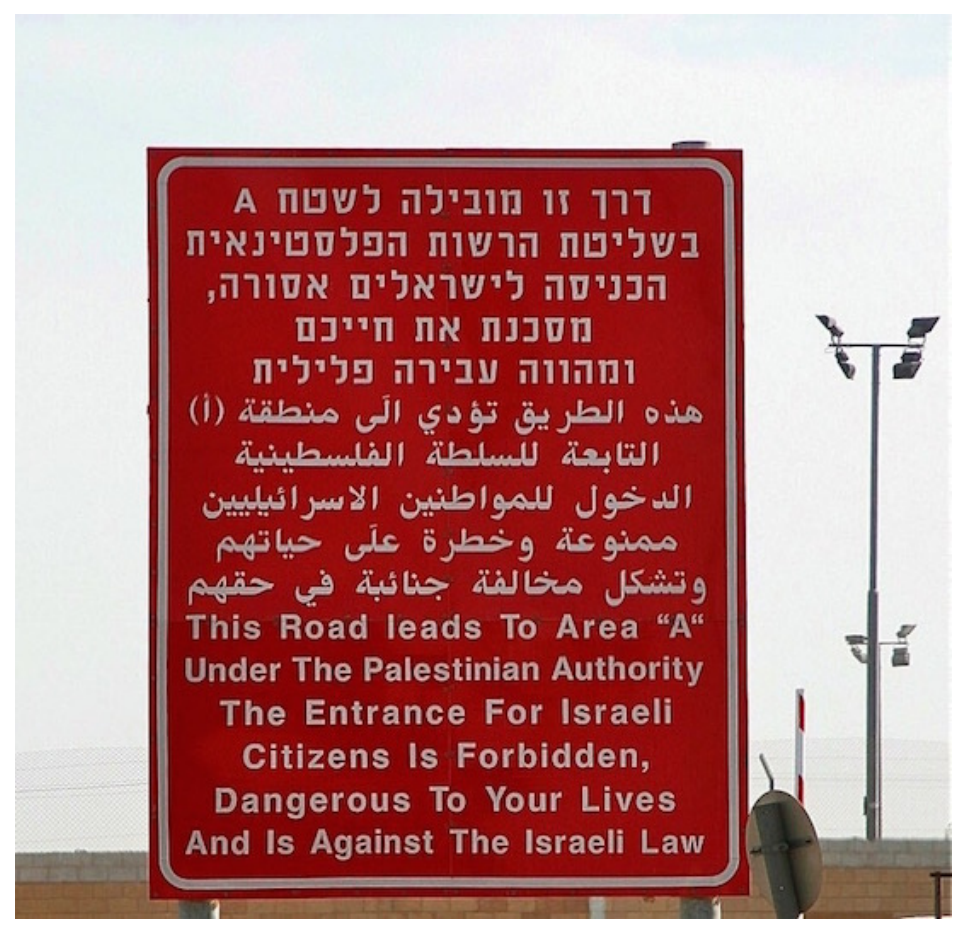

[28] I think (we) Jews needed to be Chosen to give them (us) hope - in the past. But in the present, it's a poisonous, hateful philosophy that results in oppression: murder, humiliation, without oppressors feeling bad about their oppressiveness because their philosophy inures them to the feelings and lives of others. They are Always Right and will do Anything To Survive. This dissociative attitude makes survivalist sense when you're struggling, but not in Israel in 2017, which increasingly resembles an abused child growing up to abuse other children. It's sweet and hopeful and understandable to toot your own horn when you have nothing but hope and a strong ego. But to continue doing so long after you've won in the most violent way is egotistical at best, psychotic at worst.

Palestine as Misdirected Revenge Fantasy

[29] Zionism sees Palestine as the Jews' movie-magic chance to take impossible revenge on people who've long since died. If there are no Nazis around in a culture steeped with Nazi-obsession, you can retroactively-in-the-present take out your fantasies on another group, however completely unrelated murdering in the present where you or your ancestors were murdered in the past. This time, you (and your side) will survive. Palestinians are surviving and it freaks Zionists out because it's so familiar, but the sides are all wrong. Zionism needs Jews to always be victorious underdogs hence Palestine-in-theZionist-mind is the worst example of not learning from trauma. 28$]$ Palestine is an accessible revenge fantasy that speaks to pan-human desires. I say this because a huge percentage of Israeli Jews have no connection to the Holocaust in Europe not just in terms of direct trauma but, for example, there are Israeli Jews whose close ancestors were Yishuv (pre-Israel) Jews who lived in Palestine pre-1948, Ethiopian 
Jews and Mizrahi Jews who came from Iraq, Morocco and Yemen, etc. Narratively, however, this may be irrelevant, because cultural fears created by understandably traumatized Ashkenazi Jews create a vengeful bloodlust permeating all Jews in Israel, even those with no direct connection. This speaks to universal fears and desires that anyone can connect to and run with.

Palestine as old standby, familiar ghost

[30] All the specialness we thought was ours; all the "normalness" we wanted was never us. There is no "normal" - no "natural" — despite the scapegoating of Jews as "abnormal" for however long by

European anti-Semitism and the scapegoating of Palestinians in the same manner.229] "Normal" is an idea that differs regionally, epochally. "Normal" is colloquially defined as "moral" or "good" but normal definitionally means perpendicular, or average. So what's "normal?" Nothing. A ploy; a tool for keeping people in line. Jews as innumerable diverse groups throughout history were never normal, nor abnormal, nor special. We just needed something to help us survive. But wait. Palestinians need things too:

survival, to be special, to not be special, perpendicular, whatever. People's desires and personalities are particular but in general, we'd prefer not to be humiliated and erased and dead. On the whole, I'd say all people want to be free. $\frac{[30]}{.6}$

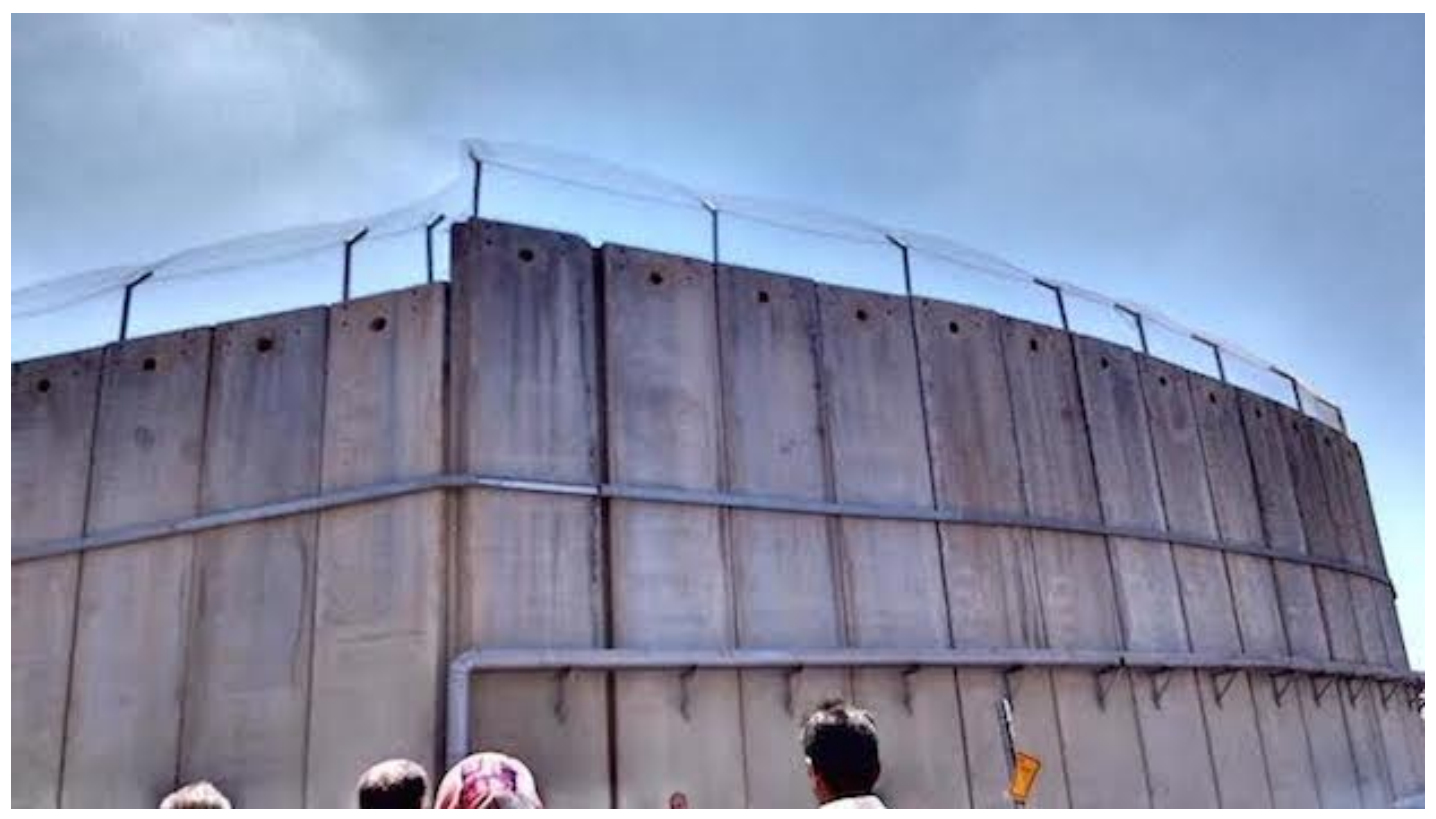

[31] Israel would do well to give up its fatally self-righteous magical thinking, its self-congratulatory isolation and overreactive defensiveness of a dream that never existed. ${ }^{[31]}$ Zionism is a collection of old and useful fantasies grown toxic by overuse; chronologically necessary self-aggrandizement that's rotted into hatred of everyone. In our obsession with Palestine, we fail to see Palestine. Palestine, to Zionism, is a nightmare fantasy, an unreal actuality-impediment to people who've gone crazy by outliving themselves as victims. Zionism is the subject of this fantasy about Palestine in the same vein as all the 
people who appear in our dreams are us - the dreamers - ourselves. Jews, I want to tell us something: We are OK now. Let's let it slip off into obsolescence. Let's give us a hug. Let's go for a walk. Let's put down these guns. Wow, so many guns. Border police, soldiers, settlers, civilians... Let's just start gun by gun...

\section{Notes}

1. Cathexis is a psychoanalytic term essentially meaning a source of incredible feeling. Etymologically Greek, "cathexis" is roughly translated from Freud's German term "Besetzung" to render the subject of intense emotional, libidinal preoccupation, e.g. "as a sensuous circus aficionado, the circus is highly cathected to me." See Peter Gay (1989, p. 456).

2. For history and ideology, see Shlomo Avineri (1984).

3. See Judith Butler's comments on disconnecting Jewishness from Zionism in her remarks about BDS - boycott, divestment and sanctions - at Brooklyn College in 2013. Here's one snippet: "When Zionism becomes co-extensive with Jewishness, Jewishness is pitted against the diversity that defines democracy, and if I may say so, betrays one of the most important ethical dimensions of the diasporic Jewish tradition, namely, the obligation of co-habitation with those different from ourselves.... It also demeans the important struggles in which Jews and Palestinians work together to stop the wall, to rebuild homes, to document indefinite detention, to oppose military harassment at the borders and to oppose the occupation and to imagine the plausible scenarios for the Palestinian right to return."

4. See Kristeva's work on the "abject," the horror of disorientation and the real and imagined breakdown between self and other in confrontation with violent reality in considering unconscious dimensions to this conflict.

5. Psychoanalytically, one could think of the "Uses of Others" idea in terms of transference, the clinical process wherein the past feelings of the patient are unconsciously projected onto the present embodiment of the therapist. Transference is a healthy way to reenact past trauma and fantasies etc. by releasing them (verbally) in order to understand them. The converse experience of the patient influencing the therapist is called countertransference. See more in Judy Kantrowitz's The Patient's impact on the Analyst (1996). Sociologically, otherness is used to differentiate hierarchically. See more in many works of bell hooks, e.g. 1994, 2000, 2004, 2009, 2014.

6. Part of an amazing 1963 documentary following James Baldwin in San Francisco, Take this Hammer https://www.youtube.com/watch?v=4AFA98fuexA.

7. For an amazing sample of Jacqueline Rose's The Question of Zion (2005), please see this interview: https://www.opendemocracy.net/conflict-debate 97/zionism 2766.jsp. "... that rigidification of identity which the state justifies in terms of such a history, ensures that every catastrophe that happens to Israel becomes a confirmation of its view of itself. It leads to a fortification of the soul. This distressing overlap between the need to feel safe as a nation and the need to believe in yourself takes on the form of a repetition of trauma. Here you really need a psychoanalytic distinction. Israel is now the fourth most militarily powerful nation in the world. It is a nuclear power. It is not in danger. The fear that Israel will be destroyed is groundless. But that does not mean that it isn't real. The fear is real and it is understandable. This is the difficult territory: you have to say both things at once. But, as I said earlier, when the fear becomes an 
identity that justifies itself by a violence that cannot acknowledge itself as violence, something has gone terribly wrong."

8. True story. For more, see http://www.salon.com/2010/04/15/star_david_swastika_open2010/.

9. See Jacqueline Rose, (2005), on nationalism, particularly Netanyahu's use thereof, as remedy to past Jewish trauma. On p. 126, for example: "Netanyahu urges on the Jewish people the need to foster an identification with the most lethal components of statehood as the answer to their own history. It was the historic task of Zionism, specifically of Herzl and Jabotinsky, to empower the Jews, against all those critics who warned that the establishment of Jewish military might would throw the Jews into the arms of militarism and extreme nationalism."

10. A common refrain in Israel, with various iterations against various peoples in various periods (the players change, the game remains the same-style) For several examples, see http://mondoweiss.net/2016/05/azarya-king-israel/ (including https://www.youtube.com/watch? $\mathrm{v}=\mathrm{yrVmhPnHAR8}$ ) and https://electronicintifada.net/blogs/ali-abunimah/video-death-arabs-marchforces-its-way-through-occupied-jerusalem.

11. "As of 9 March 2016, 182 Palestinians, including 44 children, were killed by the IOF and settlers since October 2015" according to Al Haq human rights organization in Ramallah. See http://972mag.com/new-video-shows-accused-stabber-posed-no-threat-when-shot/112593/.

12. You may also be interested in this wonderful and accessible primer on the history of the Palestine/lsrael conflict: http://www.merip.org/primer-palestine-israel-arab-israeli-conflict-new.

13. Normalization of violence. For more, see: http://972mag.com/using-deadly-force-againstpalestinians-as-a-first-resort/112416/.

14. See http://972mag.com/my-friend-is-in-jail-for-something-he-wrote-on-facebook/113553/.

15. Israeli academic Nurit Peled-Elhanan is the author of the book Palestine in Israeli School Books: Ideology and Propaganda in Education (2012). An interview with Peled-Elhanan can be viewed here: https://www.youtube.com/watch?v=pWKPRC-_oSg.

16. Let us turn to activist-professor and New Historian Ilan Pappe in this clear and informal video talking about Israeli foundational myths of righteous victimhood: https://www.youtube.com/watch? $\mathrm{v}=\mathrm{s} I \mathrm{WvcBzbqV}$.

17. As visually explained in the comics of Eli Valley: http://www.elivalley.com/comics/israel-man-anddiaspora-boy/?rq=diaspora\%20boy. As Landy points out, "Talk of sedentary diaspora Jews who have lived for generations in the same country as being "in exile" serves to create a false symmetry of relationships with Palestinian refugees and effaces the differences between symbolic chosen exile and actual forced exile." (2011, p. 51)

18. As Edward Said put it, "all the transformative projects for Palestine, including Zionism, have rationalized the denial of present reality in Palestine with some argument about a 'higher' (or better, more worthy, more modern, more fitting; the comparatives are almost infinite) interest, cause or mission. These 'higher' things entitle their proponents not only to claim that the natives of Palestine, such as they are, are not worth considering and therefore nonexistent." (1979, p. 15)

19. For more on violence as symptom, as stanched desire for intimacy (rather than static state, purely historical or bio-inevitable phenomenon), I recommend Ken Corbett's Boyhoods: Rethinking Masculinities (2009), which socio-psychologically dissects anxieties of femininity and "phallic narcissism" in understanding the violence imbued in masculinity; Robert Karen's Becoming Attached, (1994), on how early relationships infrastructurally affect our "capacity to love" and what happens when security and consistency are withheld from infants and children; as well as the 
major works of Donald Winnicott and Erik Erikson).

20. See right-wing settler youth in various states of nationalistic revelry for more:

https://www.youtube.com/watch?v=Mdaf1I_sHcc.

21. See Palestinian activist Issa Amro talking with Israeli settler leader Noam Arnon for more: https://www.youtube.com/watch?v=vtkgYwVOEHU.

22. See Benny Morris (1994).

23. Regarding imperialist mind schemas, Said said, "the distinction between an idea that one feels to be one's own and a piece of land that one claims by right to be one's own (despite the presence on the land of its working native inhabitants) is really nonexistent... in the world of nineteenthcentury culture out of which imperialism developed. Laying claim to an idea, laying claim to a territory." (1979, p. 73)

24. Coping mechanisms have excellent, maintenance purposes but they aren't necessarily sustainable. Transference is a helpful concept here. When a coping mechanism overextends its expiration date and is no longer helpful, one is stuck developmentally in the past. One could say one is transferring something from the past into the present without learning from it or moving on. What was protective (if not workable, to say nothing of salvational) in the past may hurt - if not emended or transcended - in the present.

25. See Said in general, and The Question of Palestine's chapter entitled "Zionism from the Standpoint of its Victims" in particular. "Once victims themselves, Occidental Jews in Israel have become oppressors (of Palestinian Arabs and Oriental Jews.) (Said, 1979, p. 69).

26. In her 2012 book Israel/Palestine and the Queer International Sarah Schulman says that grandiosity is born of unconscious awareness that one is wrong. "As long as Israel falsely creates Palestine as an inferior parter, it will never be able to solve problems with Palestine. Since all human beings have, as the Lebanese LGBT organization Helem says, 'Inalienable' rights, to refuse to engage is pathological. It is a kind of grandiosity born, I believe. from the hidden yet present knowledge that one's own behaviour is unjustified. Refusing to engage is to choose the facade over truth, to reject accurate knowledge of one's actual self. And so, the Israeli 'silencing mechanism' is a pathological behavior designed to protect a delusion of superiority. And it requires escalated upkeep," (p. 125).

27. The Jew as Exile is pivotal to Jewish self-conception "but crucially Jews are not now in exile. The term 'exile' in an appropriation from both Jewish history and Palestinian reality... One recalls Finkielkraut's condemnation of himself and other post-Holocaust Jews for building their identity on the appropriation of Jewish suffering that they did not in fact suffer. Nostalgia for marginalisation does not indicate the experience of marginalisation. If anything the reverse is true," (Landy, 2011, p. 50).

28. Though, as Rose said, "in psychoanalytic parlance, the nation will fail to project. Seeing enemy as outside threat only, Israel was sowing the seeds of long-term damage within." (2005, p. 72).

29. See Jacqueline Rose, Question of Zion (2005, p. 76).

30. Does Israel - to use the talking points - have a mystical hatred-necessitating "right to exist?" Said Hannah Arendt: "He (Herzl) did not realise that the country he dreamt of did not exist, that there was no place on earth where a people could live like the organic national body that he had in mind and that the real historical development of a nation does not take place inside the closed walls of a biological entity." See Arendt (1945, p. 156). 


\section{Works Cited}

Arendt, Hannah. "Zionism Reconsidered." Menorah Journal, 32/2 (1945): 162-196.

Avineri, Shlomo. The Making of Modern Zionism: The Intellectual Origins of the Jewish State. $2^{\text {nd }}$ edition. New York: Basic Books, 1984.

Butler, Judith. "Judith Butler's Remarks to Brooklyn College on BDS." The Nation. (2013). Retrieved from https://www.thenation.com/article/judith-butlers-remarks-brooklyn-college-bds.

Cohen, Mark. Under Crescent and Cross. Princeton, NJ: Princeton University Press, 1994.

Corbett, Ken. Boyhoods: Rethinking Masculinities. New Haven, CT: Yale University Press, 2009.

Gay, Peter. The Freud Reader. New York: W.W. Norton, 1989.

Karen, Robert. Becoming Attached: First Relationships and How They Shape Our Capacity to Love. New York: Oxford University Press, 1994.

Khalek, Rania. "Palestinian Lives Don't Matter to US Media." The Electronic Intifada. (2015) Retrieved from https://electronicintifada.net/blogs/rania-khalek/palestinian-lives-dont-matter-us-media.

Kristeva, Julia. Powers of Horror: An Essay on Abjection. Trans. Leon S. Roudiez. New York: Columbia University Press, 1982.

Landy, Daniel. Jewish Identity and Palestinian Rights: Diaspora Jewish Opposition to Israel, London: Zed Books, 2011.

Lavie,Smadar. "Mizrahi Feminism and the Question of Palestine." Journal of Middle East Women's Studies 7/2 (2011): 56-88.

Menocal, María Rosa. The Ornament of the World. New York: Little Brown \& Company, 2002.

Morris, Benny. 1948 and After: Israel and the Palestinians. Oxford: Clarendon Press, 1994.

Peled-Elhanan, Nurit. Palestine in Israeli School Books: Ideology and Propaganda in Education. London: I.B. Tauris, 2012.

Rose, Jacqueline. The Question of Zion. Princeton, NJ: Princeton University Press, 2005.

Said, Edward. The Question of Palestine. New York: Vintage Books, 1979.

Schulman, Sarah. Israel/Palestine and the Queer International. Durham, NC: Duke University Press, 2012.

Silberstein, Laurence J. Martin Buber's Social and Religious Thought: Alienation and the quest for meaning. New York: New York University Press, 1989. 
Tavris, Carol. The Mismeasure of Woman: Why Women Are Not the Better Sex, the Inferior Sex, or the Opposite Sex. New York: Simon \& Schuster, 1992. Lay Psychoanalysis Resources for Thought.

Blecher, Rosemary and Rose, Jacqueline. "Nation as trauma, Zionism as question: Jacqueline Rose interview." openDemocracy. (2005) Retrieved from https://www.opendemocracy.net/conflictdebate 97/zionism 2766.jsp.

Butler, Judith. "Palestine and Nationhood After the Subject" European Graduate School Video Lectures. (2009). Retrieved from https://www.youtube.com/watch?v=5VxZ3X6Z3ro.

Chalquist, Craig. "A Glossary of Freudian Terms." (2001) Retrieved from http://www.terrapsych.com/freud.html.

Freud, Sigmund. "The Moses of Michelangelo." Translated by James Strachey. (1914) Retrieved from http://users.clas.ufl.edu/burt/filmphilology/FreudMoses.pdf.

Freud, Sigmund. Group Psychology and The Analysis of The Ego (e-book) Translated by James Strachey. (2011) Retrieved from http://www.gutenberg.org/files/35877/35877-h/35877-h.htm.

Institute of Psychoanalysis. "What is Psychoanalysis?" (2011) Retrieved from https://www.youtube.com/watch?v=uM2FGc0wDg8.

London Review of Books. "Jacqueline Rose on Zionism, Freud, Sylvia Plath and more." (2015) Retrieved from https://www.youtube.com/watch?v=D-qyuEBL0-o.

Massad, Joseph. Desiring Arabs. Chicago: University of Chicago Press, 2007.

Nordheimer Nur, Ofer. Eros and Tragedy: Jewish Male Fantasies and the Masculine Revolution of Zionism. Brighton, MA: Academic Studies Press, 2014.

"The Qouch: The Queer Psychoanalysis Society. Psychoanalysis and Queer Theory Resources." Retrieved from https://theqouch.com/psychoanalysis-and-queer-theory-resources/.

The Society for Psychoanalytic Inquiry. "Resistance and Resistance." (2015) Retrieved from https://www.youtube.com/watch?v=vMId9GMJ N8.

Cite this Article

https://doi.org/10.20415/rhiz/031.e05 